\title{
Is noma an infectious disease? Is it transmissible?
}

\author{
A Gayet-Ageron $^{1 *}$, D Baratti-Mayer ${ }^{2}$, D Courvoisier ${ }^{3}$, D Pittet $^{1}$, GESNOMA $^{1}$ \\ From International Conference on Prevention \& Infection Control (ICPIC 2011) \\ Geneva, Switzerland. 29 June - 2 July 2011
}

\section{Introduction / objectives}

Noma is a devastating facial necrosis affecting young children in developing countries. The causative agents are not well identified, in particular the association of noma with specific microbiological agents and the risk for transmission.

\section{Methods}

Prospective matched case-control study conducted in Zinder, Niger, between September 2001 and October 2006. Epidemiological, socio-behavioural, and biological determinants were collected through interviews with children and their representatives and during clinical examinations. Conditional logistic regression was applied.

\section{Results}

A total of 82 acute noma cases and 327 controls were recruited. The noma epidemic curve declined during the study-period $(P=0.04)$ with no seasonal effect $(P=0.74)$. There was no intra-family case, but an older sibling rank was associated with a higher odds of developing noma $\left(\mathrm{OR}>=3^{\text {rd }}\right.$ position 3.51 ; 95\%CI: $\left.1.57-7.85\right)$. Noma was also associated with severe wasting (OR 7.79; 3.89-15.57), severe stunting (OR 5.22; 2.73-9.97), a higher number of past pregnancies in the mother (OR 1.19 for each additional child; 1.08-1.32), the presence for any other disease within the last 3 months (OR 3.52; 1.89-6.54) or family posses no chicken at home, as aproxy for poverty (OR $2.53 ; 1.32-4.82)$. No association was observed between noma and serological status to various viruses (EBV, VZV, HSV, CMV, Morbillivirus). Definitive microbiological data will be available at time of the meeting.

\section{Conclusion}

Noma is linked with poor general health status leading to a higher risk to develop opportunistic illnesses, which

${ }^{1}$ Infection Control Program, Geneva, Switzerland

Full list of author information is available at the end of the article precipitates the occurrence of devastating facial lesions. No epidemiological evidence was shown for cross-transmission in this cohort- the largest reported to the best of our knowledge.

\section{Disclosure of interest}

None declared.

\section{Author details}

${ }^{1}$ Infection Control Program, Geneva, Switzerland. ${ }^{2}$ University Hospitals Of Geneva, Geneva, Switzerland. ${ }^{3}$ Division of Clinical Epidemiology, University Hospitals of Geneva, Geneva, Switzerland.

Published: 29 June 2011

doi:10.1186/1753-6561-5-S6-P251

Cite this article as: Gayet-Ageron et al:: Is noma an infectious disease? Is it transmissible? BMC Proceedings 2011 5(Suppl 6):P251.

Submit your next manuscript to BioMed Central and take full advantage of:

- Convenient online submission

- Thorough peer review

- No space constraints or color figure charges

- Immediate publication on acceptance

- Inclusion in PubMed, CAS, Scopus and Google Scholar

- Research which is freely available for redistribution

\section{Ciomed Central}

